\title{
Vitamin D: a natural inhibitor of multiple sclerosis
}

\author{
Colleen E. Hayes \\ Department of Biochemistry, University of Wisconsin-Madison, 433 Babcock Drive, Madison, Wisconsin 53706, USA
}

\begin{abstract}
Inheriting genetic risk factors for multiple sclerosis (MS) is not sufficient to cause this demyelinating disease of the central nervous system; exposure to environmental risk factors is also required. MS may be preventable if these unidentified environmental factors can be avoided. MS prevalence increases with decreasing solar radiation, suggesting that sunlight may be protective in MS. Since the vitamin D endocrine system is exquisitely responsive to sunlight, and MS prevalence is highest where environmental supplies of vitamin $\mathrm{D}$ are lowest, we have proposed that the hormone, 1,25-dihydroxycholecalciferol $\left(1,25-(\mathrm{OH})_{2} \mathrm{D}_{3}\right)$, may protect geneticallysusceptible individuals from developing MS. Evidence consistent with this hypothesis comes not only from geographic studies, but also genetic and biological studies. Over-representation of the vitamin D receptor gene $b$ allele was found in Japanese MS patients, suggesting it may confer MS susceptibility. Fish oil is an excellent vitamin D source, and diets rich in fish may lower MS prevalence or severity. Vitamin D deficiency afflicts most MS patients, as demonstrated by their low bone mass and high fracture rates. However, the clearest evidence that vitamin D may be a natural inhibitor of MS comes from experiments with experimental autoimmune encephalomyelitis (EAE), a model of MS. Treatment of mice with 1,25- $(\mathrm{OH})_{2} \mathrm{D}_{3}$ completely inhibited EAE induction and progression. The hormone stimulated the synthesis of two antiencephalitogenic cytokines, interleukin 4 and transforming growth factor $\beta-1$, and influenced inflammatory cell trafficking or apoptosis. If vitamin D is a natural inhibitor of MS, providing supplemental vitamin D to individuals who are at risk for MS would be advisable.
\end{abstract}

Vitamin D: 1,25-Dihydroxycholecalciferol: Multiple sclerosis: Experimental autoimmune encephalomyelitis: Autoimmunity

Multiple sclerosis (MS) is a central nervous system demyelinating disease of uncertain aetiology (Ebers, 1998). Genetic epidemiological studies demonstrate that genetic risk factors determine susceptibility and account for familial clustering of MS (for review, see Ebers \& Dyment, 1998). Biological first-degree relatives of MS patients show a 20to 40-fold increased risk of disease compared with unrelated individuals. However, no single locus controlling MS development has been identified, suggesting that genetic MS susceptibility may be polygenic, as originally postulated by Pratt et al. (1951).

Importantly, inheriting MS susceptibility factors is not sufficient for disease development, as evidenced by the finding that $70 \%$ of monozygotic twin pairs are discordant for MS (Ebers et al. 1986). Thus, exposure to one or more environmental risk factors is necessary for MS development. Since infections often precede the onset of MS symptoms and/or exacerbations (Sibley et al. 1985; Anderson et al. 1993; Panitch, 1994), an infectious MS aetiology has been proposed (for review, see Noseworthy, 1999). Despite intense investigation, compelling evidence for this hypothesis has not been forthcoming, and other disease-determining environmental risk factors must be sought.

MS prevalence shows a striking geographic distribution. It increases with increasing latitude in both hemispheres (for example, see Davenport, 1922; Ulett, 1948; Limburg, 1950; Kurland, 1952), from a low of one to two cases per $10^{5}$ population near the equator to a high of $>200$ cases per $10^{5}$ population at latitudes $>50^{\circ}$. This peculiar distribution suggests that one disease-determining environmental risk factor is somehow linked to latitude. Acheson et al. (1960) examined many latitude-linked variables, and showed that average annual hours of sunlight and average 
December daily solar radiation showed a highly significant inverse correlation $(r-0 \cdot 80)$ with MS prevalence. They concluded that sunshine "could conceivably act directly - a certain skin dose of sunshine per unit time protecting the individual in some way'.

Epidemiological studies are confounded by the problem of separating genetic and environmental influences. However, some evidence from studies involving genetically similar populations reinforces the possibility that sunlight may be protective in MS. In Switzerland, districts at low altitudes $(\leq 1000 \mathrm{~m})$ have high MS rates, whereas districts at high altitudes $(\geq 2000 \mathrm{~m})$ have low MS rates, despite the relative genetic similarity of the two populations (Kurtzke, 1967). This anomaly may reflect the increased short-wavelength u.v. radiation received at high altitudes compared with low altitudes (Geiger, 1965). Further, within genetically similar migrating populations, those migrating to regions with increased solar radiation had reduced MS rates, whereas those migrating to regions with decreased solar radiation had increased MS rates (for review, see Ebers \& Sadovnick, 1994). The benefits of sunlight accrued to migrating individuals of all ages (Hammond et al. 2000). Together these epidemiological studies indicate that MS may be a preventable disease in individuals who are genetically at risk, if the pertinent environmental risk factors can be correctly identified and avoided. Sunlight appears to be the protective environmental factor linked to latitude.

\section{Sunlight, the vitamin D endocrine system and multiple sclerosis}

The vitamin D endocrine system is exquisitely responsive to sunlight. Sunlight is required for precholecalciferol synthesis in skin (Velluz \& Amiard, 1949), and precholecalciferol is the precursor of the biologically active hormone, 1,25-dihydroxycholecalciferol $\quad\left(1,25-(\mathrm{OH})_{2} \mathrm{D}_{3}\right.$; Holick et al. 1971; Norman et al. 1971). Goldberg (1974a, b) first proposed that sunlight might protect individuals from developing MS through the actions of $1,25-(\mathrm{OH})_{2} \mathrm{D}_{3}$, since geographic areas with low supplies of vitamin $\mathrm{D}$ due to low-intensity solar radiation and inadequate dietary vitamin D correlated with regions of high MS prevalence. Conversely, MS prevalence is low where vitamin D is abundant, as in sunny climates, high altitudes and areas with diets rich in fish oil. We reinforced this hypothesis (Hayes et al. 1997), and provided strong experimental evidence from the experimental autoimmune encephalomyelitis (EAE) model in mice, summarized later (p. 533), showing that $1,25-(\mathrm{OH})_{2} \mathrm{D}_{3}$ is a natural inhibitor of the autoimmunemediated processes that underlie MS (Cantorna et al. 1996, 1998; Nashold et al. 2000).

All vertebrates, including human subjects, obtain their vitamin D requirement mainly from exposure of their skin to sunlight rather than from their diet (Holick, 1995). The energy of u.v. B photons that penetrate the epidermis is absorbed by the abundant cholesterol metabolite 7-dehydrocholesterol, rupturing the $\mathrm{C}-9-\mathrm{C}-10$ bond and yielding an unstable intermediate, precholecalciferol. This compound spontaneously undergoes an internal sigmatropic shift of a proton and isomerization to the thermodynamically-stable cholecalciferol. Cholecalciferol is transported from the skin to the liver bound to the serum vitamin D-binding protein. In hepatocytes C-25 hydroxylation produces the major circulating form of vitamin D, 25-hydroxycholecalciferol, which is biologically inactive at physiological concentrations. In the kidney, a further $\mathrm{C}-1$ hydroxylation forms the biologically active hormone, $1,25-(\mathrm{OH})_{2} \mathrm{D}_{3}$ (Holick et al. 1971; Norman et al. 1971). The production of the hormone is highly regulated by the need for $\mathrm{Ca}$ and $\mathrm{P}$.

Latitude and season affect the intensity of solar radiation reaching the earth's surface and, therefore, the rate of cholecalciferol synthesis (Webb et al. 1988). In Boston, MA $\left(42^{\circ} \mathrm{N}\right)$, human skin exposed to sunlight produced no precholecalciferol from November to February due to insufficient intensity of solar radiation. Further north in Edmonton, Canada $\left(52^{\circ} \mathrm{N}\right)$, this period of no precholecalciferol synthesis extended from October to March. In Los Angeles, CA $\left(34^{\circ} \mathrm{N}\right)$, cholecalciferol synthesis occurred throughout the year. Individuals living at northerly or southerly latitudes who do not eat vitamin D-rich foods or supplements become vitamin D deficient during the winter.

\section{Genetic evidence for the vitamin D - multiple sclerosis hypothesis}

Evidence consistent with the hypothesis that vitamin D may be a natural inhibitor of MS comes from geographic (discussed earlier), genetic and biological studies. The hormone exerts most of its biological effects only after it has bound to the vitamin D hormone receptor (VDR; Haussler et al. 1997). New genetic evidence indicates that one allele of the VDR gene may be associated with MS susceptibility. Fukazawa et al. (1999) found over representation of the VDR gene $b$ allele (chromosome 12q14) in Japanese MS patients. This allele is distinguished by a BsmI endonuclease site, and it was also implicated in susceptibility to insulindependent diabetes mellitus in Indian Asians (McDermott et al. 1997). In Canadian families Steckley et al. (2000) found no association between MS and genetic markers at the VDR locus, the nearby gene encoding the 25-hydroxycholecalciferol 1- $\alpha$-hydroxylase (12q13), or the vitamin D-binding protein locus (4q12). However, the report by Fukazawa et al. (1999) indicates that a VDR polymorphism may contribute to MS susceptibility, consistent with the vitamin D - MS hypothesis.

\section{Biological evidence for the vitamin D - multiple sclerosis hypothesis}

Fish oil is a rich source of cholecalciferol, and there is limited evidence that diets rich in fish may lower the incidence and/or severity of MS. Lower MS prevalence rates are found along the Atlantic coast of Norway than inland (Swank et al. 1952; Presthus, 1960; Westlund, 1970). The coastal Norwegians consumed the equivalent of approximately $32.5 \mu \mathrm{g}$ cholecalciferol daily, about 3-fold higher than individuals living inland (Goldberg, 1974a). Furthermore, in a small clinical trial MS patients ingested cod liver oil $(20 \mathrm{~g} / \mathrm{d} ; 125 \mu \mathrm{g}$ vitamin D/d), along with $\mathrm{Ca}$ and $\mathrm{Mg}$ supplements, which reportedly lowered their rate of exacerbations (Goldberg et al. 1986). A second small trial of 
fish oil also lessened MS symptoms (Bates et al. 1989). These trials involved very few subjects and had other methodological shortcomings. Nevertheless, the available evidence on fish oil consumption and MS is consistent with the vitamin D - MS hypothesis.

There is clear evidence that the majority of MS patients exhibit long-term vitamin D deficiency, as characterized by low bone mass and high fracture rates. The serum 25-hydroxycholecalciferol level, the best indicator of nearterm vitamin $\mathrm{D}$ nutrition, was less than adequate $(<50 \mathrm{nmol} / \mathrm{l})$ in $69 \%$ of MS patients tested (Nieves et al. 1994). In addition, MS patients had significantly reduced bone mass compared with their age- and gender-matched healthy peers (Nieves et al. 1994), indicative of long-term vitamin D malnutrition. A follow-up study found that MS patients lost bone mass at a 3- to 7-fold higher rate and experienced fractures at a 10-fold higher rate than their peers (Cosman et al. 1998). These findings indicate that significant vitamin D deficiency of some duration exists in most MS patients, consistent with the hypothesis that this deficiency may pose a risk factor for MS.

\section{Experimental evidence for the vitamin D - multiple sclerosis hypothesis}

The clearest evidence that vitamin $\mathrm{D}$ may be a natural inhibitor of MS comes from experiments done using the EAE system as a model of MS. Immunizing mice with spinal cord homogenate containing myelin basic protein induces a progressively paralytic autoimmune disease, EAE, with strong similarities to MS (Olitsky \& Yager, 1949). Lemire \& Archer (1991) and Branisteanu et al. (1995) used the EAE model to show that feeding a low-Ca diet and injecting 1,25- $(\mathrm{OH})_{2} \mathrm{D}_{3}$ prolonged the survival of $\mathrm{SJL} / \mathrm{J}$ mice with severe EAE, but these treatments did not completely inhibit the morbidity or mortality of the disease. We studied relapsing-remitting EAE in B10.PL mice and demonstrated that $1,25-(\mathrm{OH})_{2} \mathrm{D}_{3}$ pretreatment completely eliminated EAE, while hormone treatment at the first sign of symptoms inhibited EAE progression (Cantorna et al. 1996). The lower the dietary Ca level, the higher was the $1,25-(\mathrm{OH})_{2} \mathrm{D}_{3}$ dose needed to completely prevent EAE symptoms, suggesting that adequate dietary $\mathrm{Ca}$ is important for EAE inhibition (Cantorna et al. 1999).

In further experiments we tested the hypothesis that $1,25-(\mathrm{OH})_{2} \mathrm{D}_{3}$ might stimulate the development of antiencephalitogenic cells and the cytokines they produce (Cantorna et al. 1998). Consistent with this hypothesis, we detected interleukin 4 and transforming growth factor $\beta$ - 1 transcripts in the lymph nodes and central nervous system of hormone-treated mice, where EAE was prevented, but not in those of mock-treated mice with EAE. The interleukin 4 and transforming growth factor $\beta$ - 1 cytokines have strong antiinflammatory activity in EAE (Johns et al. 1991; Kuruvilla et al. 1991; Racke et al. 1991; Inobe et al. 1996). In other experiments we induced severe EAE, administered hormone treatment or mock treatment, and examined the central nervous system for infiltrating inflammatory cells (Nashold et al. 2000). Whereas the mock-treated mice remained severely paralysed, most hormone-treated animals regained the partial use of both hind limbs within $72 \mathrm{~h}$ of hormone treatment. Histopathological examination and flow cytometric analyses indicated that about $5 \times 10^{6}$ inflammatory macrophages were lost from the inflamed central nervous system within $24 \mathrm{~h}$ of the $1,25-(\mathrm{OH})_{2} \mathrm{D}_{3}$ treatment, suggesting a possible influence of the hormone on inflammatory cell trafficking or apoptosis.

\section{Vitamin D nutrition and multiple sclerosis}

If vitamin $\mathrm{D}$ is a natural inhibitor of MS, it would be reasonable to provide supplemental vitamin $\mathrm{D}$ to individuals who are at risk for MS. It is noteworthy that vitamin D supplementation during childhood significantly decreased the risk of type I diabetes mellitus, an autoimmune disease (EURODIAB Substudy 2 Study Group, 1999). A reassessment of vitamin D nutrition is underway, and there is good evidence that the currently recommended adequate intakes are too low (Vieth, 1999). The adequate intake for adults is currently $5 \mu \mathrm{g} / \mathrm{d}$, but this does not prevent osteoporosis and secondary hyperparathyroidism (Holick, 1998; Malabanan et al. 1998). To prevent secondary hyperparathyroidism a serum 25-hydroxycholecalciferol concentration $>50 \mathrm{nmol} / \mathrm{l}$ is required (Malabanan et al. 1998). Adults living or working in sunny environments, where MS prevalence is lowest, have circulating 25hydroxycholecalciferol levels between 105 and $163 \mathrm{nmol} / \mathrm{l}$ (Vieth, 1999). Thus, a serum 25-hydroxycholecalciferol concentration $\geq 100 \mathrm{nmol} / \mathrm{l}$ may be optimal to prevent MS. To maintain serum 25-hydroxycholecalciferol at approximately $100 \mathrm{nmol} / \mathrm{l}$ an adult who is not exposed to sunlight would need to ingest $100 \mu \mathrm{g} / \mathrm{d}$ (Vieth, 1999). This estimate is between the $95 \mu \mathrm{g} / \mathrm{d}$ that Goldberg (1974b) calculated might prevent $\mathrm{MS}$, and the $125 \mu \mathrm{g} / \mathrm{d}$ that was given in the small clinical trial of fish oil (Goldberg et al. 1986).

Very high doses of vitamin D can cause hypercalcaemia, which is potentially fatal. Accordingly, a tolerable safe upper limit for vitamin D supplementation has been set at $50 \mu \mathrm{g} / \mathrm{d}$ for age $>1$ years, and $25 \mu \mathrm{g} / \mathrm{d}$ for age $<1$ years (Holick, 1998). However, the panel that established this limit overlooked information indicating that the safe upper limit is actually much higher. Adults living or working in sunny environments easily generate $>250 \mu \mathrm{g}$ vitamin $\mathrm{D} / \mathrm{d}$ through sun exposure without adverse effects, so the safe upper limit for total vitamin D nutrition is at least $250 \mu \mathrm{g} / \mathrm{d}$ (Vieth, 1999). Moreover, all documented cases of vitamin D toxicity with hypercalcaemia involved intakes $\geq 1000 \mu \mathrm{g} / \mathrm{d}$ (Vieth, 1999). Thus, the $100 \mu \mathrm{g} / \mathrm{d}$ needed by an adult without sun exposure to maintain serum 25-hydroxycholecalciferol at approximately $100 \mathrm{nmol} / \mathrm{l}$ would be safe, since it is well below the $250 \mu \mathrm{g} / \mathrm{d}$ generated by adults living or working in sunny environments.

The $100 \mu \mathrm{g}$ vitamin D/d supplementation that might be needed to prevent MS is significantly higher than the intake required to prevent rickets, a metabolic bone disease attributable to vitamin $\mathrm{D}$ deficiency. The intake recommended to prevent rickets in children (0-18 years) living in far northern and southern latitudes is $5 \mu \mathrm{g} / \mathrm{d}$ (Holick, 1998). It is interesting to note that the geographies of rickets (Hess, 1929) and MS are very similar; the geography of rickets led Sniadecki (cited by Holick, 1995) to suggest in 1822 that sunlight might cure rickets. Regrettably, rickets continued to 
cripple children for a full century before investigators proved the benefits of sunlight or cod liver oil (Hess \& Unger, 1921; Chick et al. 1922), and cod liver oil became a winter staple for children living in northerly latitudes. The evidence that vitamin D might be a natural inhibitor of MS is compelling. Examining the benefit of vitamin D supplementation for MS prevention will require a major effort on the part of the scientific community, but it is clearly justified.

\section{Acknowledgements}

This work was supported by the National Multiple Sclerosis Society Grant RG 3107-A-2.

\section{References}

Acheson ED, Bachrach CA \& Wright FM (1960) Some comments on the relationship of the distribution of multiple sclerosis to latitude, solar radiation and other variables. Acta Psychiatrica Neurologica Scandinavica Suppl. 147, 132-147.

Anderson O, Lygner P-E, Bergström T, Andersson M \& Vahlne A (1993) Viral infections trigger multiple sclerosis relapses: A prospective seroepidemiological study. Journal of Neurology 240, 417-422.

Bates C, Cartlidge NEF, French JM, Jackson HJ, Nightenhale S, Shaw DA, Smith S, Woo E, Hawkins SA, Miller JH, Belin J, Conroy DM, Gill SK, Sidey M, Smith AD, Thompson RHS, Zilkha K, Gale M \& Sinclair HM (1989) A double-blind controlled trial of long chain n-3 polyunsaturated fatty acids in the treatment of multiple sclerosis. Journal of Neurology Neurosurgery and Psychiatry 52, 18-22.

Branisteanu DD, Waer M, Sobis H, Marcelis S, Vandeputte M \& Bouillon R (1995) Prevention of murine experimental allergic encephalomyelitis: cooperative effects of cyclosporine and $1 \alpha, 25(\mathrm{OH})_{2} \mathrm{D}_{3}$. Journal of Neuroimmunology 61, 151-160.

Cantorna MT, Hayes CE \& DeLuca HF (1996) 1,25-Dihydroxyvitamin $\mathrm{D}_{3}$ reversibly blocks the progression of relapsing encephalomyelitis, a model of multiple sclerosis. Proceedings of the National Academy of Sciences USA 93, 7861-7864.

Cantorna MT, Humpal-Winter J \& DeLuca HF (1999) Dietary calcium is a major factor in 1,25-dihydroxycholecalciferol suppression of experimental autoimmune encephalomyelitis in mice. Journal of Nutrition 129, 1966-1971.

Cantorna MT, Woodward WD, Hayes CE \& DeLuca HF (1998) 1,25-Dihydroxyvitamin $\mathrm{D}_{3}$ is a positive regulator for the two anti-encephalitogenic cytokines TGF- $\beta 1$ and IL-4. Journal of Immunology 160, 5314-5319.

Chick H, Dalyell EJ, Hume M, Mackay HMM \& Smith HH (1922) The etiology of rickets in infants: prophylactic and curative observations at the Vienna University Kinderklinik. Lancet $\mathbf{i}$, $7-12$.

Cosman F, Nieves J, Komar L, Ferrer G, Herbert J, Formica C, Shen V \& Lindsay R (1998) Fracture history and bone loss in patients with MS. Neurology 51, 1161-1165.

Davenport CB (1922) Multiple sclerosis from the standpoint of geographic distribution and race. Archives of Neurology and Psychiatry 8, 51-58.

Ebers GC (1998) The pathogenesis of multiple sclerosis. European Journal of Neurology 5, Suppl. 2, S7-S8.

Ebers GC, Bulman DE, Sadovnick AD, Paty DW, Warren S, Hader W, Murray TJ, Seland TP, Duquette P, Gray T, Nelson R, Nicolle M \& Brunet D (1986) A population-based twin study in multiple sclerosis. New England Journal of Medicine 315, $1638-1642$.
Ebers GC \& Dyment DA (1998) Genetics of multiple sclerosis. Seminars in Neurology 18, 295-299.

Ebers GC \& Sadovnick AD (1994) The role of genetic factors in multiple sclerosis susceptibility. Journal of Neuroimmunology 54, $1-17$.

EURODIAB Substudy 2 Study Group (1999) Vitamin D supplement in early childhood and risk for Type I (insulindependent) diabetes mellitus. Diabetologia 42, 51-54.

Fukazawa T, Yabe I, Kikuchi S, Sasaki H, Hamada T, Miyasaka K \& Tashiro K (1999) Association of vitamin D receptor gene polymorphism with multiple sclerosis in Japanese. Journal of Neurological Sciences 166, 47-52.

Geiger R (1965) The Climate Near the Ground, pp. 442-446. Cambridge, MA: Harvard University Press.

Goldberg P (1974a) Multiple sclerosis: Vitamin D and calcium as environmental determinants of prevalence (a viewpoint). Part 1: Sunlight, dietary factors and epidemiology. International Journal of Environmental Studies 6, 19-27.

Goldberg P (1974b) Multiple sclerosis: Vitamin D and calcium as environmental determinants of prevalence (a viewpoint). Part 2: Biochemical and Genetic Factors. International Journal of Environmental Studies 6, 121-129.

Goldberg P, Fleming MC \& Picard EM (1986) Multiple sclerosis: decreased relapse rate through dietary supplementation with calcium, magnesium, and vitamin D. Medical Hypotheses 21, 193-200.

Hammond SR, English DR \& McLeod JG (2000) The age-range of risk of developing multiple sclerosis. Evidence from a migrant population in Australia. Brain 123, 968-974.

Haussler MR, Haussler CA, Jurutka PW, Thompson PD, Hsieh JC, Remus LS, Selznick SH \& Whitfield GK (1997) The vitamin D hormone and its nuclear receptor: molecular actions and disease states. Journal of Endocrinology 154, 557-573.

Hayes CE, Cantorna MT \& DeLuca HF (1997) Vitamin D and multiple sclerosis. Proceedings of the Society for Experimental Biology and Medicine 216, 21-27.

Hess AF (1929) Rickets, Osteomalacia and Tetany, pp. 38-61. Philadephia, PA: Lea \& Febiger.

Hess AF \& Unger LF (1921) Cure of infantile rickets by sunlight. Journal of the American Medical Association 39, 77-82.

Holick MF (1995) Environmental factors that influence the cutaneous production of vitamin D. American Journal of Clinical Nutrition 61, Suppl., 638S-645S.

Holick MF (1998) Vitamin D requirements for humans of all ages: new increased requirements for women and men 50 years and older. Osteoporosis International Suppl. 8, S24-S29.

Holick MF, Schnoes HK \& DeLuca HF (1971) Identification of 1,25-dihydroxycholecalciferol, a form of vitamin $\mathrm{D}_{3}$ metabolically active in the intestine. Proceedings of the National Academy of Sciences USA 68, 803-804.

Inobe JI, Chen Y \& Weiner HL (1996) In vivo administration of IL-4 induces TGF-beta-producing cells and protects animals from experimental autoimmune encephalomyelitis. Annals of the New York Academy of Sciences 778, 390-392.

Johns LD, Flanders KC, Ranges GE \& Sriram S (1991) Successful treatment of experimental allergic encephalomyelitis with transforming growth factor- $\beta 1$. Journal of Immunology 147, $1792-1796$.

Kurland LT (1952) The frequency and geographic distribution of multiple sclerosis as indicated by mortality statistics and morbidity surveys in the United States and Canada. American Journal of Hygiene 55, 457-476.

Kurtzke JF (1967) On the fine structure of the distribution of multiple sclerosis. Acta Neurologica Scandinavica 43, 257-282.

Kuruvilla AP, Shah R, Hochwald GM, Liggitt HD, Palladino MA \& Thorbecke GJ (1991) Protective effect of transforming growth factor b1 on experimental autoimmune diseases in mice. 
Proceedings of the National Academy of Sciences USA 88, 2918-2921.

Lemire JM \& Archer DC (1991) 1,25-Dihydroxyvitamin $\mathrm{D}_{3}$ suppresses the in vivo induction of murine experimental autoimmune encephalomyelitis. Journal of Clinical Investigation 87, 1103-1107.

Limburg CC (1950) Geographic distribution of multiple sclerosis and its estimated prevalence in the US. Proceedings of the Association for Research into Nervous Diseases 28, 15-24.

McDermott MF, Ramachandran A, Ogunkolade BW, Aganna E, Curtis D, Boucher BJ, Snehalatha C \& Hitman GA (1997) Allelic variation in the vitamin $\mathrm{D}$ receptor influences susceptibility to IDDM in Indian Asians. Diabetologia 40, 971-975.

Malabanan A, Veronikis IE \& Holick MF (1998) Redefining vitamin D insufficiency. Lancet 351, 805-806.

Nashold FE, Miller DJ \& Hayes CE (2000) 1,25-Dihydroxyvitamin D3 treatment decreases macrophage accumulation in the CNS of mice with experimental autoimmune encephalomyelitis. Journal of Neuroimmunology 103, 171-179.

Norman AW, Myrtle JF, Midgett RJ, Nowicki HG, Williams V \& Popjak G (1971) 1,25-dihydroxycholecalciferol: identification of the proposed active form of vitamin D3 in the intestine. Science 173, 51-54.

Noseworthy JH (1999) Progress in determining the causes and treatment of multiple sclerosis. Nature 399, A40-A47.

Nieves J, Cosman F, Herbert J, Shen V \& Lindsay R (1994) High prevalence of vitamin $\mathrm{D}$ deficiency and reduced bone mass in multiple sclerosis. Neurology 44, 1687-1692.

Olitsky PK \& Yager RH (1949) Experimental disseminated encephalomyelitis in white mice. Journal of Experimental Medicine 90, 213-223.

Panitch HS (1994) Influence of infection on exacerbations of multiple sclerosis. Annals of Neurology 36, S25-S28.

Pratt RTC, Compston ND \& McAlpine D (1951) The familial incidence of multiple sclerosis and its significance. Brain 74, 191-232.
Presthus J (1960) Report on the multiple sclerosis investigations in West Norway. Acta Psychiatrica Neurologica Scandinavica Suppl. 147, 88-92.

Racke MK, Dhib-Jalbut S, Cannella B, Albert PS, Raine CS \& McFarlin DE (1991) Prevention and treatment of chronic relapsing experimental allergic encephalomyelitis by transforming growth factor- $\beta 1$. Journal of Immunology $\mathbf{1 4 6}$, 3012-3017.

Sibley WA, Bamford CR \& Clark K (1985) Clinical viral infections and multiple sclerosis. Lancet i, 1313-1315.

Steckley JL, Dyment DA, Sadovnick AD, Risch N, Hayes C, Ebers GC and the Canadian Collaborative Study Group (2000) Genetic analysis of vitamin D related genes in Canadian multiple sclerosis patients. Neurology $\mathbf{5 4}, \mathbf{7 2 9 - 7 3 2 .}$

Swank RL, Lerstad O, Strøm A \& Backer J (1952) Multiple sclerosis in rural Norway: Its geographic and occupational incidence in relation to nutrition. New England Journal of Medicine 246, 721.

Ulett G (1948) Geographic distribution of multiple sclerosis. Diseases of the Nervous System 9, 342.

Vieth R (1999) Vitamin D supplementation, 25-hydroxyvitamin D concentrations, and safety. American Journal of Clinical Nutrition 69, 842-856.

Velluz L \& Amiard G (1949) Chimie organique-equilibre de reaction entre precalciferol et calciferol (Organic chemistrybalance of reaction between precalciferol and calciferol). Comptes Rendus de l'Academie des Sciences 228, 853-855.

Webb AR, Kline L \& Holick MF (1988) Influence of season and latitude on the cutaneous synthesis of vitamin D3: exposure to winter sunlight in Boston and Edmonton will not promote vitamin D3 synthesis in human skin. Journal of Clinical Endocrinology and Metabolism 67, 373-378.

Westlund K (1970) Distribution and mortality time trend of multiple sclerosis and some other diseases of Norway. Acta Neurologica Scandinavica 46, 455-483. 